Conclusion: Presence of HLA-B27 in pSpA patients was associated to a higher axial and root joint involvement, an earlier disease onset and presence of AAU, but not to PSA, psoriasis and IBD that were higher in HLA-B27 negative patients.

Table 1.

\begin{tabular}{|c|c|c|c|c|c|}
\hline & \multicolumn{2}{|c|}{$\mathrm{HLA}-\mathrm{B} 27+(\mathrm{N}=118)$} & \multicolumn{2}{|c|}{ HLA-B27- $(\mathrm{N}=168)$} & \multirow[b]{2}{*}{$\mathrm{p}$} \\
\hline & $\mathrm{N} /$ mean & $\% / S D$ & $\mathrm{~N} /$ mean & $\% / S D$ & \\
\hline Obesity (BMI >30) & 14 & $11,9 \%$ & 44 & $26,3 \%$ & 0,003 \\
\hline Men & 65 & $55,1 \%$ & 83 & $49,4 \%$ & 0,344 \\
\hline Family history & 44 & $37,3 \%$ & 52 & $31,0 \%$ & 0,265 \\
\hline Axial involvement & 62 & $52,5 \%$ & 42 & $25,0 \%$ & $<0.001$ \\
\hline Radiographic sacroilitis & 30 & $28,3 \%$ & 25 & $16,8 \%$ & 0,029 \\
\hline Psoriathic arthritis & 23 & $19,5 \%$ & 112 & $72,6 \%$ & $<0.001$ \\
\hline Reactive arthritis & 5 & $4,2 \%$ & 3 & $1,8 \%$ & 0,229 \\
\hline IBD arthritis & 1 & $0,9 \%$ & 8 & $4,8 \%$ & 0,098 \\
\hline Mono/oligoarticular pattern & 59 & $54,6 \%$ & 76 & $51,0 \%$ & 0,566 \\
\hline Root joint involvement & 52 & $44,1 \%$ & 54 & $32,1 \%$ & 0,04 \\
\hline Tarsitis & 22 & $18,6 \%$ & 16 & $9,5 \%$ & 0,028 \\
\hline Enthesitis & 62 & $52,5 \%$ & 69 & $41,1 \%$ & 0,056 \\
\hline Dactylitis & 31 & $26,3 \%$ & 51 & $30,4 \%$ & 0,452 \\
\hline Peripheral structural damage & 9 & $7,6 \%$ & 41 & $24,4 \%$ & $<0.001$ \\
\hline Psoriasis & 21 & $17,8 \%$ & 125 & $74,4 \%$ & $<0.001$ \\
\hline AAU & 21 & $17,8 \%$ & 7 & $4,2 \%$ & $<0.001$ \\
\hline IBD & 2 & $1,7 \%$ & 13 & $7,7 \%$ & 0,039 \\
\hline Fibromyalgia & 15 & $13,2 \%$ & 43 & $26,7 \%$ & 0,008 \\
\hline Age (y) & 42,7 & 14,8 & 52,2 & 13,4 & $<0.001$ \\
\hline Age onset (y) & 33,9 & 13,7 & 38,3 & 14,5 & 0,013 \\
\hline Dx delay $(\mathrm{m})$ & 4,7 & 8,2 & 7,7 & 9,8 & 0,009 \\
\hline Disease duration (y) & 9,06 & 10,2 & 14,2 & 11,6 & $<0.001$ \\
\hline BASDAI & 3,9 & 2,2 & 4,4 & 2,4 & 0,06 \\
\hline CRP & 16,9 & 25,1 & 12 & 27,3 & 0,148 \\
\hline ASDAS-CRP & 2,7 & 1,2 & 2,7 & 1,1 & 0,876 \\
\hline AAU number of episodes & 6,8 & 8,4 & 2,1 & 1,7 & 0,265 \\
\hline
\end{tabular}

Disclosure of Interests: Marta Arévalo Speakers bureau: Abbvie, Nordic Pharma, Clementina López-Medina: None declared, Victoria Navarro-Compán: None declared, Mireia Moreno Speakers bureau: Abbvie, Novartis, UCB, Bristol and AMGEN, María LLop Vilaltella Speakers bureau: Novartis, Joan Calvet: None declared, Jordi Gratacos-Masmitja Speakers bureau: During the course of the year, I have received funding for courses and conferences or as an advisor and speaker from MSD, Pfizer, AbbVie, Janssen Cilag, Novartis, Celgene, and Lilly., Maxime Dougados: None declared

DOI: 10.1136/annrheumdis-2021-eular.965

\section{POS0243 WHAT DOES REMISSION IN AXIAL SPONDYLOARTHRITIS MEAN FOR CLINICIANS? AN EXPLORATORY STUDY OF 200 FRENCH RHEUMATOLOGISTS BASED ON A VIGNETTE EXERCISE INCLUDING 36 CASES AND PRIORITY RATINGS}

K. Aouad ${ }^{1}$, D. Wendling ${ }^{2}$, A. Baglin ${ }^{3}$, M. Breban ${ }^{4}$, S. Dadoun ${ }^{5,6}$, C. Hudry7, A. Moltót 8,9 , E. Pertuiset ${ }^{10}$, L. Gossec ${ }^{1}{ }^{1}$ Sorbonne University; AP-HP, Pitié Salpêtrière Hospital, Rheumatology Department, Paris, France; ${ }^{2}$ Besançon University Hospital, Rheumatology Department, Besançon, France; ${ }^{3}$ Novartis, Pharmaceutical, Ile de France, France; ${ }^{4}$ APHP, Ambroise Paré Hospital, Rheumatology Department, Boulogne, France; ${ }^{5}$ Private practice, Rheumatology, Paris, France; ${ }^{6} \mathrm{CeSOA}, \mathrm{MGEN}$ action sociale, Rheumatology, Paris, France; ${ }^{6} \mathrm{CeSOA}$, MGEN action sociale, Rheumatology, Paris, France; ${ }^{8}$ Cochin Hospital, APHP, Rheumatology Department, Paris, France; ${ }^{9}$ INSERM U-1153 (ECAMO), CRESS, Université de Paris, Rheumatology, Paris, France; ${ }^{10}$ Rene Dubos Hospital, Rheumatology Department, Pontoise, France

Background: Treat-to-target in axial spondyloarthritis (axSpA) aims to achieve and maintain clinical remission/inactive disease or alternatively, low disease activity [1]. However, there is no consensual definition of remission in axSpA: the T2T international task force has proposed Ankylosing Spondylitis Disease Activity Score (ASDAS) inactive disease, but this definition is not widely accepted $[1,2]$.

Objectives: To explore rheumatologists' perception of remission in axSpA, using vignette cases and a priority exercise.

Methods: A steering group of 7 rheumatologists designed a national cross-sectional survey during two face-to-face meetings in 2019-2020. The survey comprised 36 vignette cases: fixed elements included the clinical picture (34 year-old-male with confirmed axSpA, normal C-reactive protein (CRP), without synovitis, enthesitis, dactylitis or extra-articular manifestations) and there were 3 varying parameters (axial pain (0-10) [ranging 2 to 5], fatigue (0-10) [2 to 8], and morning stiffness [ $<15$ minutes, 30 minutes or 1 hour]. For each vignette, the rheumatologist answered binarily: "do you consider this patient in remission: yes/ no". The second part of the survey comprised a priority rating (0-10 priority and 4 top items) of elements important to consider for remission, from a list of 12 items (BASDAI, ASDAS, elements of BASDAI and ASDAS including CRP, NSAIDs use, extra-articular manifestations, and other explanations for the symptoms e.g. fibromyalgia). The analysis was descriptive.

Results: Overall, 200 French rheumatologists participated between June and September 2020. Out of 2,400 vignette evaluations (mean of 66 evaluations per vignette), 463 (19\%) were classified as remission by rheumatologists. Six vignette cases constituted $56 \%$ of all remission cases (Figure 1): these comprised a short duration of morning stiffness ( $<15$ minutes), a low VAS axial pain (2 or 3) but with varying levels of VAS fatigue. When the duration of morning stiffness increased from 15 to 30 minutes and VAS axial pain increased from 2-3 to $4-5$ independently, classification as remission decreased from $42 \%$ to $12 \%$ and from $28-33 \%$ to $5-11 \%$, respectively. However, when VAS fatigue increased, it impacted less remission.

In priority ratings, 4 items were selected as important by $68-75 \%$ of rheumatologists: morning stiffness and axial pain (both included in the vignettes), as well as extra-articular manifestations and NSAID use, whereas only $18 \%$ selected fatigue. BASDAI was cited as the 1st priority criteria by $24 \%$ of rheumatologists and ASDAS as the $2^{\text {nd }}$ by $16 \%$ of rheumatologists.

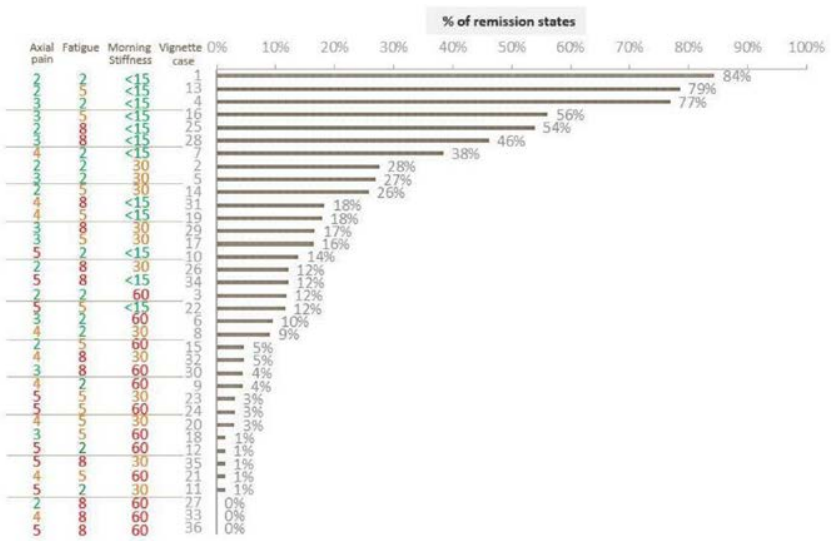

Figure 1. Frequencies of the declared remission states by rheumatologists for each of the 36 vignette cases

Conclusion: Morning stiffness, axial pain, NSAIDs use, and extra-articular manifestations seem to impact the physicians' perception of remission in axSpA whereas fatigue has less impact on remission for rheumatologists. Consensus is needed on remission in axSpA.

References: [1Smolen JS et al. Treating axial spondyloarthritis and peripheral spondyloarthritis, especially psoriatic arthritis, to target: 2017 update of recommendations by an international task force. Ann Rheum Dis 2018:77:3-17.

[2] Wendling D et al. 2018 update of French Society for Rheumatology (SFR) recommendations about the everyday management of patients with spondyloarthritis. Joint Bone Spine 2018;85:275-84.

Funding: This study was funded and organized by Novartis France Disclosure of Interests: Krystel Aouad: None declared, Daniel Wendling: None declared, Anne BAGLIN Employee of: Novartis, Maxime Breban: None declared, sabrina DADOUN: None declared, Christophe Hudry: None declared, Anna Moltó: None declared, Edouard Pertuiset: None declared, Laure Gossec: None declared

DOI: 10.1136/annrheumdis-2021-eular.1019

\section{POS0244 PATIENT JOURNEY WITH AXIAL SPONDYLOARTHRITIS: CRITICAL ISSUES FROM THE PATIENT PERSPECTIVE. RESULTS FROM THE EUROPEAN MAP OF AXIAL SPONDYLOARTHRITIS (EMAS)}

M. Garrido-Cumbrera ${ }^{1}$, D. Poddubnyy ${ }^{2}$, C. Bundy ${ }^{3}$, L. Christen ${ }^{4}$, R. Mahapatra ${ }^{5}$, S. Makri', C. J. Delgado-Domínguez ${ }^{1}$, S. Sanz-Gómez ${ }^{1}$, P. Plazuelo-Ramos ${ }^{7}$, V. Navarro-Compán ${ }^{8}$ on behalf of IMAS working group. ${ }^{1}$ Universidad de Sevilla, Health \& Territory Research (HTR), Seville, Spain; ${ }^{2}$ Charité - Universitätsmedizin Berlin, Rheumatology Department, Berlin, Germany; ${ }^{3}$ Cardiff University, School of Healthcare Sciences, Cardiff, United Kingdom; ${ }^{4}$ Novartis Pharma AG, Patient Engagement, Basel, Switzerland; ${ }^{5}$ Axial Spondyloarthritis International Federation (ASIF), Patient Advocacy, London, United Kingdom; ${ }^{6}$ Cyprus League Against Rheumatism (CYPLAR), Patient Advocacy, Nicosia, Cyprus; ${ }^{7}$ Spanish Federation of Spondyloarthritis Associations (CEADE), Presidency, Madrid, Spain; ${ }^{8}$ Hospital Universitario La Paz, IdiPaz, Madrid, Spain 